Article

\title{
Remixing News: Appropriation and Authorship in Finnish Counter-Media
}

\author{
Olli Seuri ${ }^{1, *}$ and Kim Ramstedt ${ }^{2,3}$ \\ ${ }^{1}$ Faculty of Social Sciences, Tampere University, Finland \\ ${ }^{2}$ Faculty of Arts, University of Helsinki, Finland \\ ${ }^{3}$ Faculty of Arts, Psychology and Theology, Åbo Akademi University, Finland \\ * Corresponding author (olli.seuri@tuni.fi)
}

Submitted: 29 April 2021 | Accepted: 14 September 2021 | Published: 20 January 2022

\begin{abstract}
This article outlines a first attempt at analysing counter-media publishing through the lens of remix theory. We concentrate on two key concepts-appropriation and authorship-which have a permanent standing in the remix research literature. To support our theoretical analysis, we investigate the coverage of two cases in the Finnish right-wing counter-media online publication $\mathrm{MV}$-lehti. Our findings enable new readings on the nature of both counter-media work and remix culture. In fact, counter-media publishing leans more in the direction of remix culture-which is based on the act of using pre-existing materials to produce something new - than towards traditional journalistic convention, with its rules and ethical guidelines. MV-lehti's practice of combining and layering different material is discernibly political, often resembling media activism. Our study provides the argument that counter to the utopian democratising assumptions of remix culture, the proliferation of remix practices has also given antidemocratic actors the means to challenge collectively and institutionally supported ideas of knowledge and justice. Counter-media publishing is perhaps democratising in that it offers the means to participate, but these antagonistic actors also remix news to undermine liberal-democratic ideals and social justice. Evidently, remix practices can be co-opted for a reactionary agenda.
\end{abstract}

\section{Keywords}

alternative media; appropriation; authorship; counter-media; democracy; journalism; media activism; media work; remix

\section{Issue}

This article is part of the issue "New Forms of Media Work and Its Organizational and Institutional Conditions: Issue Information" edited by Salla-Maaria Laaksonen (University of Helsinki) and Mikko Villi (University of Jyväskylä).

(C) 2022 by the author(s); licensee Cogitatio (Lisbon, Portugal). This article is licensed under a Creative Commons Attribution 4.0 International License (CC BY).

\section{Introduction}

In the early 2000s, "fake news" referred first and foremost to news satires like The Daily Show. It was a time when culture jammers and guerrilla marketers aimed to disrupt or subvert so-called mainstream media culture. Fast forward a decade or so, and a view that fake news could be an effective tool for promoting media literacy (see Baym, 2005) seems quaint at best. The media space is littered with everything from disinformation disguised as news to populist or right-wing authoritarian figures' frequent efforts to discredit legacy media by calling them fake news. Especially in the online environment, it is harder and harder to distinguish credible news sources from other forms of content, as not only satirists but also malign political actors have been savvy enough to use journalism's form and appearance to push their agenda. Throughout the Western media sphere, there has been a surge of pseudo- and sometimes semi-journalistic actors often cited as counter-media or alternative media.

In this theory-oriented study, we explore how remix as a theoretical tool can be used to analyse the work of these emerging publishers. The concept of remix has been used to describe a variety of, most often, artistic practices that appropriate and recombine existing media content to create new works. A common feature in its application has been questioning the authority of discrete authored works, often in conjunction with a call 
to democratise cultural production from dominant (economic) institutions in favour of the amateur (Gunkel, 2016; Navas et al., 2015b). Remix is, as such, not only a theory of appropriation but also a concept that describes a larger ideological position brought about with digital media technology. This ideological position has been theorised inherently as subversive and democratising, and the practice of remix and its practitioners as progressive (Navas et al., 2015a). Still, the proliferation of remix as a cultural condition has also generated practices that undermine democracy, understood in accordance with Miller (1978) to be empirically connected to principles of social justice.

This article serves as a first attempt at analysing counter-media publishing through the lens of remix theory. Rather than challenging existing research and theorisation, we aim to expand the "repertoire to interpret" (Wrona \& Gunnesch, 2016, p. 727) by focusing on two concepts crucial to remixing: appropriation and authorship. The main research question we seek to answer is as follows: What can remix theory reveal about counter-media as a relatively new form of digital publishing? In what follows, we will first outline the context of the article: remix as a theory and an ideology as well as counter-media as an antagonistic challenger to legacy media. Then, we proceed to our analysis, which is grounded in prior research and literature and complemented by two small empirical samples of countermedia stories from Finnish MV-lehti to support our theorisations. This part is divided into two sections, in which we point out how the underlying characteristics of the media work in counter-media become more comprehensible in relation to remix than to journalism. Rather than complying with journalistic ethics and practices, MV-lehti seeks to "own," or "pwn," legacy media by appropriating the media material and form to push its political agenda. The political messages are often constructed by combining and layering material from different sources. Finally, we conclude the article by discussing the larger implications of our analysis, such as co-opting of remix practices for a reactionary agenda, for both studies on remix and counter-media and offer our thoughts on how our findings can be applied for future research.

\section{Theoretical Context}

\subsection{Remix as a Theory and an Ideology}

Remix is popularly understood as referring to the practice of altering, reusing, or recombining preexisting media content to create new, often artistic, works. Although the term originally comes from the field of popular music-or more accurately, the practice developed by DJs in the 1970s to edit individual analogue tracks on a master recording to make new versions of songs that were more suitable for DJ use (Borschke, 2011)-remix is today used in a broad range of practices and associated particularly with the digital realm. As Gunkel (2016, p. 22) notes, remix has become something of a quasisynonym for terms like collage, pastiche, or mashup and an umbrella term for cultural borrowing at large.

But over and above describing individual practices of appropriation, remixing within digital media technologies has come to signify a larger cultural condition with radical political implications. As advocated most notably by copyright lawyer and activist Lessig (2008), "remix culture" is understood to be fundamentally democratising in that it questions notions of original authorship and the legitimacy of copyright legislation, promoting an open and free use of cultural products for all. In this view, remix is a materialisation of what has been theorised as "participatory cultures" (Delwiche \& Jacobs Henderson, 2013), signalling ostensibly lower barriers for artistic expression brought about by digital technology and civic engagement with functions previously monopolised by hierarchical institutions like newspapers and television stations.

Similar to claims that participation is inherently democratic and that it can exclusively be attributed to digital technology (see, for example, Carpentier, 2013; Kelty, 2016), theorisations of remix culture have not gone without their share of criticism. As Borschke (2011) notes, Lessig's conceptualisation of remix fails to acknowledge a long history of media innovation that has influenced cultural borrowing and is problematic in suggesting that digital remix cultures restore some lost values of communality and free speech in contemporary society. While this criticism is certainly valid, the proliferation of remix practices has been argued to have impacted people's perceptions of creative work and the concept of authorship (Navas et al., 2018, p. 2). We argue that this is also witnessed in the emergence and popularity of antidemocratic counter-media practices that are the subject of this study, although this dimension of remix practices is almost absent in remix research.

Debates about remix practices, as Gunkel (2016, pp. 17-19) suggests, have largely been organised around two seemingly opposing positions about creative work and copyright legislation. One side consists of remix fans and those who celebrate corresponding ways of creating media content as innovative and original, while the opposing side consists of critics, large entertainment institutions and artists who argue that remixers are lazy copycats essentially engaged in illegal activity (Gunkel, 2016, pp. 17-19). While the values they attribute to remix practices are radically different, the two positions also have a lot in common. According to Gunkel (2016, p. 20), both sides believe that they are defending universal principles, such as originality and creativity. But more than that, we maintain that both sides believe that remixing is a subversive practice that can destabilise power hierarchies.

Apart from a few notable exceptions (e.g., BrøvigHanssen \& Sinnreich, 2020; Stanovsky, 2017), remix theory has not been utilised in analyses of anti-democratic media appropriation. Stanovsky (2017) revisits Walter 
Benjamin's concerns about the aestheticisation of fascism by looking at digital meme culture as remixed racism. Brøvig-Hanssen and Sinnreich (2020) note-in their study of video remixes of speeches made by former US President Donald Trump - that authoritarian and reactionary figures often see themselves as subversive in their quest to tear down the establishment, or, in Trump's case, the mythical "deep state." Both studies focus on audiovisual media works created by individual artists. Our effort here extends remix theory to written right-wing publishing within the realm of organised counter-media actors.

In our application of remix as a theoretical tool for conceptualising counter-media work, we are interested in both the actual practices associated with remix theory and the larger ideological implications of adapting these strategies. The field of remix studies is characterised by heterogeneity, and there are no particular objects, methods, or theories that can be used to conclusively define remix principles (see Gunkel, 2016). However, by singling out two key concepts-appropriation and authorshipfrom earlier remix research as the primary tools for our analysis, we aspire for a detailed examination of countermedia as opposed to a general evaluation of the compatibility between our theoretical and empirical material. The concept of appropriation is applied as an overall tool to analyse how the new works comment, critique, recontextualise, or explicitly disregard the content and aesthetics of the source material (Navas et al., 2015b). In analysing authorship, our approach is on a more ideological level, as we scrutinise the implications of naming or neglecting to name authors. Here we are not only drawing explicitly on remix theorisations but also adapting ideas that have been proposed by Barthes (1977) and Foucault (1984). Both scholars' works have been used to describe the concept of authorship in remix practices (see, for example, da Silva, 2015; Navas, 2012; Vallier, 2018), and their ideas are, as such, already integrated into theories of remixing.

\subsection{Counter-Media as an Antagonistic Challenger to Legacy Media}

Before embarking on the actual analysis, we need to approach the conceptualisation of counter-media and its relationship to legacy media in a hybrid media system (Chadwick, 2017). These non-mainstream websites have sometimes been clumsily categorised as fake news, which has prompted scholars to generate more appropriate formulations. In recent years, these websites have been further defined as counter-media (see Hopp et al., 2020; Toivanen et al., 2021; Ylä-Anttila et al., 2019), alternative media (see Holt, 2018; Nygaard, 2020; Schulze, 2020;) and hyperpartisan media (see Heft et al., 2020; Rae, 2021). These definitions work as distinctions, not only to fake news or legacy media, but also to more traditional partisan media (Levendusky, 2013) and populist media (Norocel et al., 2020). While the idea of creating an alternative media space or acting counter to so-called mainstream media culture is not novel (e.g., Atton, 2002; Atton \& Couldry, 2003; Harcup, 2005; Kenix, 2011), the new websites rising to scholarly attention in the latter part of the 2010s have largely coalesced around the right (see Figenschou \& Ihlebæk, 2019; Haller et al., 2019; Holt, 2020).

Counter-media websites or alternative media actors differ across the spectrum of media culture (e.g., Heft et al., 2020; Ihlebæk \& Nygaard, 2021), but they do share some common characteristics. First, they are often defined by active positioning against legacy media and professional journalists. This can be summed as counterhegemonic alternativeness found at producer, content, organisational, and system levels (Holt et al., 2019). For example, most right-wing alternative media in the Nordic countries do not adhere to ethical codes of professional journalism, as they see themselves as standing in opposition to the media or serving as media critics (Ihlebæk \& Nygaard, 2021). Likewise, alternative actors in the UK, both on the left and right, are openly hostile to legacy media, based on a perceived bias and a lack of impartiality in professional journalism (Cushion et al., 2021).

Second, it is common for antagonism and counter positions to both legacy media and mainstream politics to be expressed not only through criticism but also through scepticism, conspiracism, derogatory language, and even hate (see Figenschou \& Ihlebæk, 2019; Mayerhöffer, 2021; Seuri \& Toivanen, 2021). Although there is no one transcending political orientation, different antagonistic speech acts carry clear political connotations. The politics in counter-media are apparent in varying anti-systemness (Holt, 2018), emphasis on topics like crime, immigration, and Islam (Heft et al., 2020; Nygaard, 2020) as well as published content and policy positions they express. Furthermore, scholars have noted a recent rise of a more transnationally networked political right across Europe and the United States, which has already materialised through interconnectedness in the digital right-wing media ecosystem (Heft et al., 2021).

Third, counter-media are dependent on legacy media, not only as opponents or targets of criticism but also as sources of material. There have been various scholarly definitions of this use of media material, as it has been labelled as remediation (Toivanen et al., 2021), recontextualisation and reframing (Ekman, 2019, p. 552; Haanshuus \& Ihlebæk, 2021), or produsage of reinformation (Pyrhönen \& Bauvois, 2020). Antagonistic actors use legacy media material on their websites, social media, and open media platforms. Right-wing or far-right actors have been connected to the rise of new types of online uncivil discourse (Krzyżanowski \& Ledin, 2017), as they have used different platforms, for example, to recontextualise news items to portray both overt and covert anti-Semitic discourse and Nazi propaganda (see Haanshuus \& Ihlebæk, 2021). Von Nordheim and Kleinenvon Königslöw (2021) have paid attention to the parasitic practices of these antagonistic actors infiltrating 
the journalistic system without adhering to its norms or logic. They are willing to exploit journalistic resources, as seen for example in the way Danish far-right actors used an open commentary space offered by legacy media to disseminate fear-mongering discourse and xenophobic conspiracy theories disguised as professional news and referred to as articles on social media (Farkas \& Neumayer, 2020).

We argue that the widely acknowledged antagonistic stance to legacy media and counter-media readiness to exploit or reuse legacy media material can be understood to be in accordance with subversiveness, which is often associated with remix practices. There are also certain similarities to recurring debates on remix practices, where one side might emphasise the so-called corrective nature of counter-media publishing, but the other might link it to criminal activities, such as hate speech and copyright infringements.

In this study, the Finnish outlet, MV-lehti (MV referring to the equivalent of the expression "WTF" in English), is an exemplar of counter-media publishing, as it is, so far, the most prominent counter-media actor in Finland (Heikkilä \& Väliverronen, 2019) known for its right-wing, populist, anti-immigration, and anti-elitist agenda (Tuomola, 2021; Ylä-Anttila et al., 2019). Most researchers have used the concept of counter-media to describe MV-lehti, so we follow this tradition without undermining the importance of other conceptualisations, such as alternative media. What is noteworthy in this context is that $M V$-lehti has been found to combine facts with fiction and rumours, oftentimes intentionally blurring the lines or spreading lies and other times cherry-picking, colouring, and framing information to promote its political agenda (see Tuomola, 2021; Ylä-Anttila, 2017; Ylä-Anttila et al., 2019). While there is a certain fluidity to the boundaries between legacy media and its alternatives in the Nordics (Ihlebæk \& Nygaard, 2021), in Finland, professional journalism and MV-lehti both have actively fortified these boundaries and thus stand out from each other (Seuri \& Toivanen, 2021).

\section{Analysis}

To support our theoretical analysis, we have studied two criminal news cases, which $M V$-lehti has framed as stories about immigration: a gang rape in Helsinki in March 2015 and a terrorist attack in Turku in 2017. The samples have been assembled from $M V$-lehti's archives by including all stories related to these incidents within seven days (10 March 2015-16 March 2015 and 18 August 201724 August 2017). The size of the two samples is 76 articles, with 12 in the first set and 64 in the second set. Twenty-five of these articles were designated as having explicit evidence of remix and 29 articles as having some remix-like qualities. Both categories were included in the analysis. There was some variation between the two samples, as MV-lehti had a more proven standing in the fringe media ecosystem in 2017 than in 2015. This can be seen in the number of published articles but also in more news-like stories, which, for instance, circulate information from police press releases and report on radical right-wing demonstrations (see also Toivanen et al., 2021).

To structure our reading of the counter-media articles, we have used Cover's (2013) idea of a remix analysis. Like him, we have deconstructed the articles in our study by applying a metaphor of layering (drawn from Photoshopping and digital manipulation terminology). We have studied these layers - texts, illustrations, embedded content, aspects of layout, as well as intertextual meanings-to understand what MV-lehti or its writers do with the different content used as material in their publishing. Thus, we have paid attention to both the reordering of existing material and presentations of new meanings to texts or narratives performed by layering. We conducted the research as a dialogical process, where we analysed the research material both individually and together. We began by compiling a shared spreadsheet, where we listed all remix-likequalities found in the articles with comments relating to them. This was done by identifying and highlighting how different material in the articles worked both in relation to each other and as individual layers. Then, we analysed the different layers and their functions from the perspectives of appropriation and authorship. It is worth noting that in the cases that had the most explicit remix-like qualities, the layers were also purposefully separated with typographical emphasis or with added captions. In some cases, the repurposed material could be traced back to an original source, which helped us make sense of the remix process from the perspective of the original context. The idea of this kind of research is to understand how new intertextualities are developed through the juxtaposition of different sources, or material, to give them all new significations and to activate old or new meanings (Cover, 2013). In our analysis, we have mainly concentrated on the conceptual level, as we have tried to understand appropriation and authorship in counter-media publishing.

As we have concentrated on news stories related to crime framed as issues of immigration, we understand the data is slightly tilted in the direction found to be the editorial core of $M V$-lehti. It is worth noting how, for example, Mayerhöffer (2021) found Danish right-wing alternative media to appear only moderately antagonistic and anti-hegemonic at the level of article content, as she looked at a month of published stories on several media. Still, our interest lies in the practice of remix, so we have analysed both form and content, as MV-lehti has used material from the legacy media as well as other sources to produce their stories on their website. If and when remix practices or the appropriation of legacy media material are found in counter-media publishing, traces of this practice should be found irrespective of the topic. 


\subsection{Appropriation to Change the Narrative}

The rise of alternative and counter-media websites is "an expression of the vulnerability of journalism in a globalized and digitized world" (Holt, 2020, p. 4). These sites have challenged the professionalism and the business model of news journalism, as they have cherry-picked some external features of news sites and ignored others. They benefit from the same affordances of digital publishing, platforms, and social media as well as many journalistic endeavours. For example, Nordic websites, such as Den Korte Avis, Document, Fria Tider, and MV-lehti, have a layout with highlighted content, banners, suggestions, and stories categorised with sticky headers, such as "local," "economy," and "politics." Also, their articles often resemble traditional news, at least in a superficial sense, with a headline and a lead paragraph followed by text, photos, and other content. Still, these sites are creative in applying or appropriating these features. MV-lehti mixes information and media content from different sources in a way that may be accepted within parts of the blogosphere but that is still seen as plagiarism or unethical within the traditional media context. In effect, MV-lehti was sued by two major Finnish media corporations (Sanoma and Otavamedia) for possible copyright infringements in 2015 (Marttinen, 2015).

It can be maintained that appropriation in its different forms is a central characteristic of counter-media. Their success is based on the fact that they do not act exclusively outside the norms but, rather, partially harness them whenever it suits their needs (von Nordheim \& Kleinen-von Königslöw, 2021, p. 89). For example, MV-lehti treats different media material in somewhat different ways. Whereas the legacy media materialand in some instances, assortments of Twitter and Facebook posts-are chopped and sampled, texts from the right-wing media ecosystem are circulated with added visual features and/or an endnote as a new layer, enhancing the power of the message often already included in the original text. In both instances, these original publications are appropriated in the sense of "taking something over and making it one's own" (Adema et al., 2018, p. 16). Even when MV-lehti circulates blog posts, social media posts, or readers' letters, the editors add material and edit the body of original work, resulting in a new version. For instance, the texts from a fringe academic blogger have been published word for word with additional imagery. The original posts have one or no photos, whereas the versions in MV-lehti are illustrated with photos of politicians and journalists with degrading captions. While the texts themselves are already political, a new layer, which combines text and images, is added to enhance the inflammatory nature of the publication. This layering, which discredits known politicians, academics, and journalists, can be seen as a subversive practice undermining democratic institutions (see "Hankamäki: Me emme," 2017; "Hankamäki: Valhemedian," 2017).
All in all, counter-media articles often play with text, visuals, audio, and video to alter the dynamics of the original work. They use digital means to borrow, sample, and add and subtract to build new layers of meaning. This may occur in embedded captions, photos or quotations, collages of mixed media material, and text and photo manipulations altering the meaning or creating a shock effect (see "Sipilä shokissa," 2017; "Suvakit aloittivat hyökkäyksen," 2017; "Turun Sanomat aloitti," 2017). These appropriative means are related to the rhetorical tactics of witnessing, pwning, incongruity, and noisification that Brøvig-Hanssen and Sinnreich (2020) have identified in user-generated remix videos critiquing or commenting on the policies of Donald Trump. MV-lehti, for example, is quick to point out alleged or real legacy media mistakes (witnessing), represent known politicians in unflattering and often manufactured or conflicted contexts (pwning and incongruity), and amplify certain details at the expense of the bigger picture (noisification).

The underlying aspiration in articles that appropriate legacy media news is to change the narrative or at least address the readership with an alternative to the alleged mainstream narrative. As Adema et al. (2018, p. 19) write, appropriation (in remix practices) often involves a struggle over meanings. In the case of countermedia, it is this new group of actors laying claim to traditional media resources as a means of expressing their identities, affiliations, and politics. Ylä-Anttila et al. (2019) have noted how MV-lehti engages in the political struggle both implicitly and explicitly by emphasising features that serve their anti-immigration agenda. In our data, this is most evident in the depictions of immigrants and Muslims, which range from discrediting terms ("Turun terrori-isku," 2017) to Disney-like illustrations of Middle Eastern villains ("Turun jihadistin vangitulla," 2017). This correlates with the idea of breaking taboos to push the borders of acceptability (see Nagle, 2017) and as Stanovsky (2017) has noted regarding the reactionary use of internet memes, "makes hate lovable" in that it obscures and sanitises hateful agendas.

All 25 articles found to have explicit evidence of remix incorporate different kinds of added elements or mixtures of elements, which aim to remix the original in the spirit of the equation $1+1=3$. This means they freely combine material from different sources to create additional meanings, which the original sources do not independently communicate; or, as Cover (2013) writes, the core is radically altered by what occurs at different layers. This alteration does take place in the other 29 articles with remix-like qualities too, but it is often more rudimentary or direct. In some cases, it is reminiscent of the original, analogue form of DJ-remixing, where-rather than sampling and combining material from several sourcesa designated sound in a single song is emphasised to "make a song danceable" (Borschke, 2011, p. 21). Or in this case, to make the work resonate better with the assumed audience. 
Based on these findings, we argue that the underlying characteristics of media work in counter-media websites like $M V$-lehti become more comprehensible in relation to remix culture than to journalism. Or at least, counter-media publishing leans in practice more in the direction of remixing-which is based on the act of using preexisting materials to produce something new-than towards traditional journalistic conventions with their rules and ethical guidelines.

\subsection{Contesting the Essentiality of Authorship}

The notion of authorship is at the heart of remix practices. As several authors have pointed out (e.g., Lessig, 2008; Navas, 2012; Vallier, 2018), remix challenges traditional romantic notions of original works as products that stem solely from the artist's creative mind. Countermedia actors, such as MV-lehti, also question notions of authorship. MV-lehti uses material produced by others to serve its agenda, and it rarely discloses who the persons responsible for the published articles are. Although media work has not-in a similar way to music production-been the subject of debates around authorship, the same principles apply to journalism.

We admit that journalism is not "nearly as consistent nor homogeneous as it is made out to be" (Deuze \& Witschge, 2020, p. 16), but we do believe it is important, due to our research interest, to define original reporting in journalism. Fundamentally, it means operating according to the norms and practices of professional journalism (Schudson, 2020, pp. 5-7, 23). Therefore, the question does not revert to appearance or merely form but to a larger understanding of practices and ethics, which carry ideals such as accuracy, truthfulness, transparency, and accountability as well as holding power accountable (Kovach \& Rosenstiel, 2014, p. 9). While a journalistic story is a compilation of different materials-for example, interviews, documents, press releases, and booksthe code of ethics on authorship and ownership is fairly strict in media work. In fact, both a journalist's sources and journalistic material are protected by law in many countries, although the legislative standing has become more precarious in the digital age (Posetti, 2017, p. 11). Even when traditional media cite other media as sources, they are obliged to refer to the original work like they should with a book or any other product deemed to have intellectual property rights. By denotation, the media gives credit to the first publisher of new information or the original author of a certain work.

MV-lehti is clearly indifferent to this journalistic tradition. Contrary to modern journalism, there is an absence of an assigned author. With very few exceptions, the articles in MV-lehti do not name a writer responsible for the content. This can be seen not only as a way of avoiding accountability, which we will return to shortly, but also as an attempt to appear objective. As journalism has become more author-oriented, with bylines gradually making their way into newspapers in the latter part of the 20th century (Reich, 2010) and the recent use of a photo accompanying the name, authorless and "faceless" counter-media have moved in the opposite direction. Thus, these websites seem to nod to the pre-modern news tradition, in which the news was suggested to depict a transcendent truth, a feature that was criticised by British author Forster (1925) when he wrote that newspapers took advantage of the "universal air" of anonymity.

In its practice of not naming authors, MV-lehti also attempts to avoid liability and position itself outside any petty debates on writers' politics. As Barthes (1977, p. 147) has argued in his polemic text "The Death of the Author"-which is often cited with reference to authorship in remix theory (see, for example, Navas, 2012)assigning a text an author "imposes a limit on that text." Barthes indicates that a text is rarely interpreted outside of the relationship to its author. Meanings ascribed to a work are essentially interlocked with the identity of its author. While bylines represent an indirect admission that news is "an imperfect human attempt to document it" (Reich, 2010, p. 721), the mostly authorless MV-lehti tries to rise above such mundanity. The stories often illustrate the legacy media as biased or serving an agenda, while it aspires to represent a more neutral position and champion the voice of "the people." This, of course, is a constructed position, which Tuomola (2021) has deconstructed to carry implications of ethnonationalism and antidemocratic values instead of any universal truth.

$M V$-lehti's opposition to authorship has not been total, and the website has not been able to avoid all accountability. For example, most articles in 2017 included anonymous email addresses instead of a byline with a writer's name. The ones in our data from 2015 do not have any personified information. Also, when blog posts or social media posts from the right-wing media ecosystem are circulated, the original author is referenced as a source, while the whole text is copied, and the byline consists of an email belonging to $M V$-lehti. Furthermore, the website became identified throughout the years with its founder, Ilja Janitskin (Nieminen, 2018), who at some stage began to sign at least some of the articles he had written. Willingly, or not, he became the public face of MV-lehti. According to Foucault (1984, p. 108), texts, books, and discourses historically began to have authors, so that they could be subject to punishment. This is noteworthy, as Janitskin was convicted in 2018 on 16 charges, including aggravated defamation, aggravated incitement against an ethnic group and copyright infringement (Yle, 2018).

\section{Conclusions}

While attaching concepts like détournement, culture jamming, remix, and reappropriation to news satire (e.g., Baym, 2005; McKain, 2005; Russell, 2011; Warner, 2007), media scholars have so far struggled to pin down more disruptive ways of challenging legacy media. Various 
studies on alternative and counter-media have verified a symbiosis between these websites and legacy media, as a significant part of published material links, circulates or refers to original journalism (see, for example, Holt, 2020; Nygaard, 2020; Toivanen et al., 2021). The relationship may be intrinsically asymmetrical, as "parasitic" antagonistic actors work as intermediaries at media system boundaries, drawing strength, strategies, and tools from legacy media and platforms (see Gunkel, 2001, p. 6; von Nordheim \& Kleinen-von Königslöw, 2021). It highlights how-in Chadwick's (2017) terms-different types of media not only coexist but form a system that evolves through mutual (inter)actions among older and newer media logics.

Our theoretical and empirical findings show how remix theory enables new readings on the nature of counter-media work. We assert that the act of owning in counter-media has two meanings in relation to legacy media. First, it is a form of appropriation, which means taking news or excerpts of news and using them as material for a remix. Second, it can also be interpreted as "owning" (or defeating) the legacy media, as understood in video game culture. A remix is an act of defiance of mainstream politics and so-called mainstream media culture. While MV-lehti challenges the ideas of news publishing, it does so with an attitude of not giving too much weight to rules or norms found in traditional media work. In fact, it tries to game the system by appropriating the legacy media material and form and exploiting the affordances of the platforms and social media to push its political agenda.

Furthermore, as previous research (see Ihlebæk \& Nygaard, 2021) has suggested, counter-media actors have managed to exert increasing influence on the public agenda through active social media strategies and controversial reporting. We believe counter-media also benefit from their appropriative practices understood here as rule-breaking or controversial and creative use of legacy media material. More emphasis should be put on the practices, which deviate from professional media work. In particular, populist actors on the right are strategic in their news coverage based on actual news. While counter-media like $M V$-lehti use traceable sources to create a sense of legitimacy, the layers-as in texts, illustrations, embedded content, aspects of layout, as well as intertextual meanings-added to original material can, in many cases, be considered examples of a borderline discourse of uncivility (see Haanshuus \& Ihlebæk, 2021; Krzyżanowski \& Ledin, 2017).

Thus, we propose that counter-media publishing should be seen as a form of political activism or, in some cases, media criticism akin to left-wing culture jamming. Like their predecessors or counterparts on the left, rightwing populist counter-media actors contest the centrality of authorship and stand against the increased focus on the personified author in mainstream media culture. Also, MV-lehti uses common remix practices, such as copy-paste, photo manipulation, and shock effects as lay- ers, which alter or skew original meanings. But instead of playing with the aesthetics of polished advertising like Adbusters, MV-lehti seems to reflect more DIY-like techniques found on bulletin boards and blogs, which have served as a seedbed for the right-wing radicalisation of young men. In addition, while there is some common ground with the left in speaking the language of the unprivileged, the target of criticism is different. The culture jammers of the early 2000s attacked the mass media and consumerism (Lasn, 1999), whereas MV-lehti and its equivalents believe they are fighting a multicultural mainstream hegemony.

This brings us to the appropriation of remix practices for undemocratic, populist, or authoritarian means. Remix practices have been championed for questioning notions of individual authorship and romantic ideals of a solitary artist genius. In challenging these assumptions, however, one romantic ideal appears to have been substituted for another: that participatory cultures are unequivocally subversive and democratising. Evidenced by the parallels our analysis draws between remix theory and right-wing counter-media work, we argue that the proliferation or remix practices has also given antidemocratic actors the tools to dispute collectively and institutionally supported ideas of knowledge and justice. Remix culture, as it has been theorised by Lessig (2008), is perhaps democratising in that it offers more people the means to participate in civil society, but all the forms that this participation takes certainly do not advance democratic ideals or social justice.

This study offers a diverse agenda for further research. First, it would be worthwhile to study different counter-media actors at work to get a more concise picture of their methods and means in relation to remix practices. Second, we encourage other researchers to lay out plans to scrutinise similarities and differences between left-wing media activism and right-wing counter-media publishing more closely. Third, based on the evidence here, the impact of the libertarian values advocated loudly in remix theory on the proliferation of right-wing counter-media could be worth investigating in more detail. Questioning hegemonic institutions in the discourse around culture and arts has been seen as a subversive practice that amplifies marginalised voices. Still, more attention could be given to the way this campaigning for free culture may enforce incentives to doubt institutionalised information for the purpose of advancing an antidemocratic agenda.

\section{Acknowledgments}

Olli Seuri's work was conducted under the auspices of the research project Flows of Power-Media as Site and Agent of Politics, funded by The Academy of Finland (320286). Kim Ramstedt's research has been supported by The Society of Swedish Literature in Finland and Kone Foundation. 


\section{Conflict of Interests}

The authors declare no conflict of interests.

\section{References}

Adema, J., Aufderheide, P., Billard, T., Borsche, D., burrough, X., Close, S., Coppa, F., Dufour, F., Elsayed, Y., Figueres, P., Forelle, M. C., Gallagher, O., Gunkel, D. J., Harrison, N. Heter, T. S., Jenkins, H., Kanai, A., KeiferBoyd, K., . . . Yang, E. (2018). Appropriation. In E. Navas, O. Gallagher, \& x. burrough (Eds.), Keywords in remix studies (pp. 14-42). Routledge.

Atton, C. (2002). Alternative media. SAGE.

Atton, C., \& Couldry, N. (2003). Introduction to special issue on alternative media. Media, Culture and Society, 25(5), 579-586.

Barthes, R. (1977). The death of the author. In R. Barthes \& S. Heath (Eds.), Image music text (pp. 145-148). Fontana Press.

Baym, G. (2005). The Daily Show: Discursive integration and the reinvention of political journalism. Political Communication, 22(3), 259-276. https://doi.org/ $10.1080 / 10584600591006492$

Borschke, M. (2011). Rethinking the rhetoric of remix. Media International Australia, 141(1), 17-25.

Brøvig-Hanssen, R., \& Sinnreich, A. (2020). Do you wanna build a wall? Remix tactics in the age of Trump. Popular Music and Society, 43(5), 1-15.

Carpentier, N. (2013). A short history of participation in the cultural realm. In P. Runnel, P. PruulmannVengerfeldt, P. Viires, \& M. Laak (Eds.), The digital turn: User's practices and cultural transformations (pp. 207-221). Peter Lang.

Chadwick, A. (2017). The hybrid media system: Politics and power (2nd ed.). Oxford University Press.

Cover, R. (2013). Reading the remix: Methods for researching and analysing the interactive textuality of remix. M/C Journal, 16(4). https://doi.org/ 10.5204/mcj.686

Cushion, S., McDowell-Naylor, D., \& Thomas, R. (2021). Why national media systems matter: A longitudinal analysis of how UK left-wing and right-wing alternative media critique mainstream media (2015-2018). Journalism Studies, 22(5), 633-652. https://doi.org/ 10.1080/1461670X.2021.1893795

da Silva, C. I. (2015). Can I borrow your proper name? Remixing signatures and the contemporary author. In E. Navas, O. Gallagher, \& x. burrough (Eds.), The Routledge companion to remix studies (pp. 96-103). Routledge.

Delwiche, A., \& Jacobs Henderson, J. (2013). Introduction. What is participatory culture? In A. Delwiche \& J. Jacobs Henderson (Eds.), The participatory cultures handbook (pp. 3-9). Routledge.

Deuze, M., \& Witschge, T. (2020). Beyond journalism. Polity.

Ekman, M. (2019). Anti-immigrant sentiments and mobi- lization on the internet. In K. Smets, K. Leurs, M. Georgiou, S. Witterborn, \& R. Gajjala (Eds.), The SAGE handbook of media and migration (pp. 551-62). SAGE.

Farkas, J., \& Neumayer, C. (2020). Mimicking news: How the credibility of an established tabloid is used when disseminating racism. Nordicom Review, 41(1), 1-17. https://doi.org/10.2478/nor-2020-0001

Figenschou, T. U., \& Ihlebæk, K. A. (2019). Media criticism from the far-right: Attacking from many angles. Journalism Practice, 13(8), 901-905. https://doi.org/ 10.1080/17512786.2019.1647112

Forster, E. M. (1925). Anonymity: An enquiry. The Calendar of Modern Letters, 2(9), 145-156.

Foucault, M. (1984). What is an author? In P. Rabinow (Ed.), Foucault reader (pp. 101-120). Pantheon Books.

Gunkel, D. J. (2001). Hacking cyberspace. Westview Press.

Gunkel, D. J. (2016). Of remixology. MIT Press.

Haanshuus, B. P., \& Ihlebæk, K. A. (2021). Recontextualising the news: How antisemitic discourses are constructed in extreme far-right alternative media. Nordicom Review, 42(S1), 37-50. https://doi.org/ 10.2478/nor-2021-0005

Haller, A., Holt, K., \& de La Brosse, R. (2019). The "other" alternatives: Political right-wing alternative media. Journal of Alternative \& Community Media, 4(1), 1-6. https://doi.org/10.1386/joacm_00039_2

Hankamäki: Me emme tarvitse sharia-murhaajia [Hankamäki: We don't need sharia assassins]. (2017, August 20). MV-lehti. https://mvlehti.net/2017/08/ 20/hankamaki-me-emme-tarvitse-sharia-murhaajia

Hankamäki: Valhemedian likaiset legendat [Hankamäki: The dirty legends of lying press]. (2017, August 23). MV-lehti. https://mvlehti.net/2017/08/ 23/hankamaki-valhemedian-likaiset-legendat

Harcup, T. (2005). "I'm doing this to change the world": Journalism in alternative and mainstream media. Journalism Studies, 6(3), 361-374. https://doi.org/ 10.1080/14616700500132016

Heft, A., Knüpfer, C., Reinhardt, S., \& Mayerhöffer, E. (2021). Toward a transnational information ecology on the right? Hyperlink networking among right-wing digital news sites in Europe and the United States. The International Journal of Press/Politics, 26(2), 484-504. https://doi.org/10.1177/1940161220963 670

Heft, A., Mayerhöffer, E., Reinhardt, S., \& Knüpfer, C. (2020). Beyond Breitbart: Comparing right-wing digital news infrastructures in six western democracies. Policy and Internet, 12(1), 20-45. https://doi.org/ 10.1002/poi3.219

Heikkilä, H., \& Väliverronen, J. (2019). Mediaaccountability in the era of fake news: Journalistic boundary work and its problems in Finland. In T. Eberwein, S. Fengler, \& M. Karmasin (Eds.), Media accountability in the era of post-truth politics: 
European challenges and perspectives (pp. 55-68). Routledge.

Holt, K. (2018). Alternative media and the notion of antisystemness: Towards an analytical framework. Media and Communication, 6(4), 49-57. http://dx.doi.org/ $10.17645 / \mathrm{mac} . v 6 \mathrm{i} 4.1467$

Holt, K. (2020). Right-wing alternative media. Routledge. Holt, K., Figenschou, T. U., \& Frischlich, L. (2019). Key dimensions of alternative news media. Digital Journalism, 7(7), 860-869. https://doi.org/10.1080/ 21670811.2019.1625715

Hopp, T., Ferrucci, P., \& Vargo, C. J. (2020). Why do people share ideologically extreme, false, and misleading content on social media? A self-report and trace databased analysis of counter-media content dissemination on Facebook and Twitter. Human Communication Research, 46(4), 357-384. https://doi.org/ 10.1093/hcr/hqz022

Ihlebæk, K. A., \& Nygaard, S. (2021). Right-wing alternative media in the Scandinavian political communication landscape. In E. Skogerb $\varnothing, \varnothing$. Ihlen, N. N. Kristensen, \& L. Nord (Eds.), Power, communication, and politics in the Nordic countries (pp. 263-282). Nordicom. https://doi.org/10.48335/9789188855299-13

Kelty, C. (2016). Participation. In B. Peters (Ed.), Digital keywords. A vocabulary of information society \& culture (pp. 227-241). Princeton University Press.

Kenix, L. J. (2011). Alternative and mainstream media: The converging spectrum. Bloomsbury Academic.

Kovach, B., \& Rosenstiel, T. (2014). The elements of journalism: What newspeople should know and the public should expect (3rd ed.). Crown.

Krzyżanowski, M., \& Ledin, P. (2017). Uncivility on the web: Populism in/and the borderline discourses of exclusion. Journal of Language and Politics, 16(4), 566-581. https://doi.org/10.1075/jlp.17028.krz

Lasn, K. (1999). Culture jam: The uncooling of America. William Morrow.

Lessig, L. (2008). Remix: Making art and commerce thrive in the hybrid economy. Bloomsbury.

Levendusky, M. S. (2013). Why do partisan media polarize viewers? American Journal of Political Science, 57(3), 611-623. https://doi.org/10.1111/ajps.12008

Marttinen, M. (2015, August 13). Otavamedia ja Sanoma oikeustoimiin MV-lehteä vastaan [Otavamedia and Sanoma take legal action against MV-lehti]. Journalisti. https://www.journalisti.fi/artikkelit/2015/9/ 0.22648400-143927588024

Mayerhöffer, E. (2021). How do Danish right-wing alternative media position themselves against the mainstream? Advancing the study of alternative media structure and content. Journalism Studies, 22(2), 119-136. https://doi.org/10.1080/1461670X. 2020.1814846

McKain, A. (2005). Not necessarily not the news: Gatekeeping, remediation, and The Daily Show. The Journal of American Culture, 28(4), 415-430.

Miller, D. (1978). Democracy and social justice. British
Journal of Political Science, 8(1), 1-19.

Nagle, A. (2017). Kill all normies: Online culture wars from 4chan and Tumblr to Trump and the alt-right. Zero Books.

Navas, E. (2012). Remix theory. Springer.

Navas, E., Gallagher, O., \& burrough, x. (Eds.). (2015a). The Routledge companion to remix studies. Routledge.

Navas, E., Gallagher, O., \& burrough, x. (2015b). Introduction. In E. Navas, O. Gallagher \& x. burrough (Eds.), The Routledge companion to remix studies (pp. 1-12). Routledge.

Navas, E., Gallagher, O., \& burrough, x. (2018). Introduction. In E. Navas, O. Gallagher \& x. burrough (Eds.), Keywords in remix studies (pp. 1-13). Routledge.

Nieminen, T. (2018, February 18). Ilja Janitskin loi ja hylkäsi MV-lehden, ja nyt hän kääntää selkänsä sen kannattajille-“Olen saanut tarpeekseni isänmaallisten skenestä, siitä pelleilystä" [Ilja Janitskin created and rejected MV-lehti, and now he is turning his back on its supporters- "I have had enough of the patriotic scene, of all those antics"]. Helsingin Sanomat. https://www.hs.fi/sunnuntai/ art-2000005569875.html

Norocel, O. C., Saresma, T., Lähdesmäki, T., \& Ruotsalainen, M. (2020). Discursive constructions of white Nordic masculinities in right-wing populist media. Men and Masculinities, 23(3/4), 425-446. https://doi.org/10.1177/1097184X18780459

Nygaard, S. (2020). Boundary work: Intermedia agendasetting between right-wing alternative media and professional journalism. Journalism Studies, 21(6), 766-782. https://doi.org/10.1080/1461670X. 2020.1722731

Posetti, J. (2017). Protecting journalism sources in the digital age. Unesco.

Pyrhönen, N., \& Bauvois, G. (2020). Conspiracies beyond fake news: Produsing reinformation on presidential elections in the transnational hybrid media system. Sociological Inquiry, 90(4), 705-731.

Rae, M. (2021). Hyperpartisan news: Rethinking the media for populist politics. New Media \& Society, 23(5), 1117-1132. https://doi.org/10.1177/ 1461444820910416

Reich, Z. (2010). Constrained authors: Bylines and authorship in news reporting. Journalism, 11(6), 707-725. https://doi.org/10.1177/1464884910379708

Russell, A. (2011). Networked. A contemporary history of news in transition. Polity.

Schudson, M. (2020). Journalism. Why it matters. Polity.

Schulze, H. (2020). Who uses right-wing alternative online media? An exploration of audience characteristics. Politics and Governance, 8(3), 6-18. https:// doi.org/10.17645/pag.v8i3.2925

Seuri, O., \& Toivanen, P. (2021). Fortifying boundariesThe "how and why" of the Finnish media and countermedia from 2014 to 2018. Journalistica, 15(1), 59-89. https://doi.org/10.7146/journalistica.v15i1.125038 
Sipilä shokissa. Kansalaispalaute: "Pidä nyt jumalauta Sipilä turpas jo kiinni!" [Sipilä in shock. Citizen feedback: "Shut your goddamn mouth, Sipilä!"]. (2017, August 19). MV-lehti. https://mvlehti.net/ 2017/08/19/sipila-shokissa-kansalaispalaute-pidanyt-jumalauta-sipila-turpas-jo-kiinni

Stanovsky, D. (2017). Remix racism: The visual politics of the "alt-right." Journal of Contemporary Rhetoric, $7(2 / 3), 130-138$.

Suvakit aloittivat hyökkäyksen Jussi Halla-ahoa ja MVlehteä vastaan [Social justice warriors launched an attack on Jussi Halla-aho and MV-lehti]. (2017, August 21). MV-lehti. https://mvlehti.net/2017/ 08/21/suvakit-mobiloivat-hyokkayksen-jussi-hallaahoa-ja-mv-lehtea-vastaan

Toivanen, P., Nelimarkka, M., \& Valaskivi, K. (2021). Remediation in the hybrid media environment: Understanding counter-media in context. New Media \& Society. Advance online publication. https://doi. org/10.1177/1461444821992701

Tuomola, S. (2021). Who are you, the people? Nordicom Review, 42(S1), 51-65. https://doi.org/10.2478/nor2021-0006

Turun jihadistin vangitulla uskonveljellä tuore tuomio raiskauksesta [The arrested religious brother of the Turku jihadist has a recent conviction for rape]. (2017, August 21). MV-lehti. https://mvlehti.net/2017/08/ 21/turun-jihadistin-vangitulla-uskonveljella-tuoretuomio-raiskauksesta

Turun Sanomat aloitti säälipisteiden keräämisen suomalaisnaisia Turussa teurastaneelle jihadistille! [Turun Sanomat started amassing pity for a jihadist who slaughtered Finnish women in Turku!]. (2017, August 19). MV-lehti. https://mvlehti.net/2017/08/ 19/turun-sanomat-aloitti-saalipisteiden-keraamisen- suomalaisnaisia-turussa-teurastaneelle-jihadistille

Turun terrori-isku: Toinen eilen kiinni otetuista muslimeista pidätettiin [Turku terrorist attack: Second Muslim of the two caught yesterday arrested]. (2017, August 24). MV-lehti. https://mvlehti.net/2017/08/ 24/turun-terrori-isku-toinen-eilen-kiinni-otetuistamuslimeista-pidatettiin

Vallier, J. (2018). Authorship. In E. Navas, O. Gallagher, $\& \mathrm{x}$. burrough (Eds.), Keywords in remix studies (pp. 33-42). Routledge.

von Nordheim, G., \& Kleinen-von Königslöw, K. (2021). Uninvited dinner guests: A theoretical perspective on the antagonists of journalism based on Serres" parasite. Media and Communication, 9(1), 88-98. https:// doi.org/10.17645/mac.v9i1.3419

Warner, J. (2007). Political culture jamming: The dissident humor of "The Daily Show With Jon Stewart." Popular Communication, 5(1), 17-36. https://doi.org/ 10.1080/15405700709336783

Wrona, T., \& Gunnesch, M. (2016). The one who sees more is more right: How theory enhances the "repertoire to interpret" in qualitative case study research. Journal of Business Economics, 86, 723-749. https:// doi.org/10.1007/s11573-015-0799-8

Ylä-Anttila, T. (2017). The populist toolkit. Finnish populism in action 2007-2016. University of Helsinki.

Ylä-Anttila, T., Bauvois, G., \& Pyrhönen, N. (2019). Politicization of migration in the counter-media style: A computational and qualitative analysis of populist discourse. Discourse, Context and Media, 32, 1-8. https://doi.org/10.1016/j.dcm.2019.100326

Yle. (2018). Anti-immigrant agitator Ilja Janitskin gets 22month jail sentence. https://yle.fi/uutiset/osasto/ news/anti-immigrant_agitator_ilja_janitskin_gets_ 22-month_jail_sentence/10463931

\section{About the Authors}

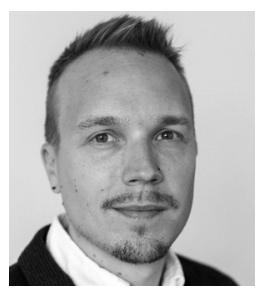

Olli Seuri is a postdoctoral researcher affiliated with the Faculty of Social Sciences at Tampere University. In recent years he has focused on a variety of issues related to journalism and its boundaries in the hybrid media environment. Seuri is also an award-winning journalist, and he has previously worked as a professor of practice in journalism (2019-2020) at the Faculty of Information Technology and Communication Sciences at Tampere University.

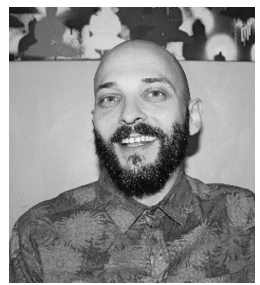

Kim Ramstedt is a postdoctoral researcher affiliated with the University of Helsinki and the independent research association Suoni. His research has mostly focused on mediation, movement, and race relations in music. After his doctoral dissertation, Ramstedt has studied the digital mediation of music and culture in the context of the Swedish speaking population in Finland and is currently investigating how whiteness and colour-blind racism informs discourses and scholarship about music in Finland. 